\title{
Ring-Chain Tautomerism of the Condensation Products of 2-Mercaptobenzohydrazide with Aliphatic and Aromatic Aldehydes: Influence of Electronic and Steric Factors
}

\author{
Andrei Yu Ershov1*, Igor V. Lagoda², Marina Yu Vasileva1, Stanislav I. Yakimovich ${ }^{3}$, \\ Boris V. Chernitsa' ${ }^{1}$, Lyudmila Yu Kuleshova4, Lyudmila V. Pavlova ${ }^{2}$, Aleksandr V. Yakimansky ${ }^{1}$ \\ ${ }^{1}$ Institute of Macromolecular Compounds, Russian Academy of Sciences, Saint Petersburg, Russia \\ ${ }^{2}$ Scientific Research Test Center, Institute of Military Medicine, Saint Petersburg, Russia \\ ${ }^{3}$ Saint Petersburg State University, Saint Petersburg, Russia \\ ${ }^{4}$ I. P. Pavlov Ryazan State Medical University, Ryazan, Russia \\ Email: *ershov305@mail.ru
}

How to cite this paper: Ershov, A.Y., Lagoda, I.V., Vasileva, M.Y., Yakimovich, S.I., Chernitsa, B.V., Kuleshova, L.Y., Pavlova, L.V. and Yakimansky, A.V. (2017) Ring-Chain Tautomerism of the Condensation Products of 2-Mercaptobenzohydrazide with Aliphatic and Aromatic Aldehydes: Influence of Electronic and Steric Factors. Open Access Library Journal, 4: e3584.

https://doi.org/10.4236/oalib.1103584

Received: April 7, 2017

Accepted: May 9, 2017

Published: May 12, 2017

Copyright $\odot 2017$ by authors and Open Access Library Inc.

This work is licensed under the Creative Commons Attribution International License (CC BY 4.0). http://creativecommons.org/licenses/by/4.0/

\section{Open Access}

\begin{abstract}
It has been shown by ${ }^{1} \mathrm{H}$ and ${ }^{13} \mathrm{C}$ NMR spectroscopy that 2-mercaptobenzoylhydrazones of aliphatic and aromatic aldehydes exist in solution as tautomeric mixtures of linear and cyclic benzo-1,3,4-thiadiazepine forms. The linear hydrazone form is represented by $(E, E)$ - and $(E, Z)$-conformational isomers, differing in the disposition relative to the amide $\mathrm{C}-\mathrm{N}$ bond. Growing bulk of the alkyl substituent at the $\mathrm{C}=\mathrm{N}$ bond of the aliphatic aldehydes derivatives decreases the fraction of the cyclic tautomer; therewith the logarithms of the constants of the chain-ring tautomeric equilibrium correlate with the $E_{\mathrm{S}}$ steric constants of the alkyl substituents. In the series of the aromatic aldehydes 2mercaptobenzoylhydrazones the linear tautomer prevails, and the logarithms of the tautomeric equilibrium constants $K_{\mathrm{T}}$ correlate with the $\sigma$-constants of the substituents in the aromatic nucleus.
\end{abstract}

\section{Subject Areas \\ Organic Chemistry}

\section{Keywords}

Hammett and Taft Equations, Ring-Chain

Tautomerism 2-Mercaptobenzoylhydrazones, Benzo-1,3,4-Thiadiazepines

\section{Introduction}

The tendency of functionally-substituted hydrazones to undergo intramolecular 
cyclization at the polar $\mathrm{C}=\mathrm{N}$ bond of the hydrazone fragment is commonly used in the synthesis of five- and six-membered heterocycles [1] [2] [3]. This reaction is sometimes reversible, which leads to the coexistence of the hydrazone and cyclic forms as their tautomeric mixture in solution [4] [5] [6]. Thus, the 2mercaptobenzoylhydrazone of acetone transforms in solution to the alternative 1,3,4-benzothiadiazepine form [7]. We note that the hydrazones obtained using the hydrazides of 2-hydroxy- and 2-aminobenzoic acids have linear structure. The possible cyclization at the $\mathrm{C}=\mathrm{N}$ bond by attack of the available $\mathrm{OH}$ or $\mathrm{NH}$ functions does not occur [8] [9].

The aim of the present work, being a continuation of the previous investigations, was to study the structure of the products of condensation of 2-mercaptobenzoic acid hydrazide $\left(2-\mathrm{HSC}_{6} \mathrm{H}_{4} \mathrm{CONHNH}_{2}\right) 1$ with a series of aliphatic and aromatic aldehydes, and also the effect of the steric or electronic properties of a substituent in the aldehyde component on the position of the tautomeric equilibrium (Figure 1 and Figure 2).

\section{Results and Discussion}

Compounds $2 \mathrm{a}-\mathbf{2} \mathrm{h}$ and $\mathbf{3 a - 3 h}$ were obtained in $55 \%$ - $90 \%$ yield after briefly maintaining equimolar quantities of 2-mercaptobenzoic acid hydrazide 1 and the appropriate aldehyde during $10-15 \mathrm{~min}$ in methanol solution at room temperature (Experimental part). In all experiments, the ${ }^{1} \mathrm{H}$ - and ${ }^{13} \mathrm{C}-\mathrm{NMR}$ spectra were recorded at definite time intervals starting from the moment of dissolution until the end of transformations. In addition, the structure of the compounds under study in the crystalline state was confirmed by solid-phase high-resolution ${ }^{13} \mathrm{C}-\mathrm{NMR}$ spectroscopy (CPMAS).

The variation in time of the ${ }^{1} \mathrm{H}-\mathrm{NMR}$ spectra of compounds $2 \mathrm{a}-2 \mathrm{~h}$ suggests that they exist in the crystalline state in the cyclic benzo-1,3,4-thiadiazepine form $\mathbf{B}$. For instance, in the freshly prepared solution of compound $2 \mathbf{a}$ in $\mathrm{DMSO}_{6}$ a single set of peaks is observed corresponding just to $\mathrm{B}$ form in ${ }^{1} \mathrm{H}$ -

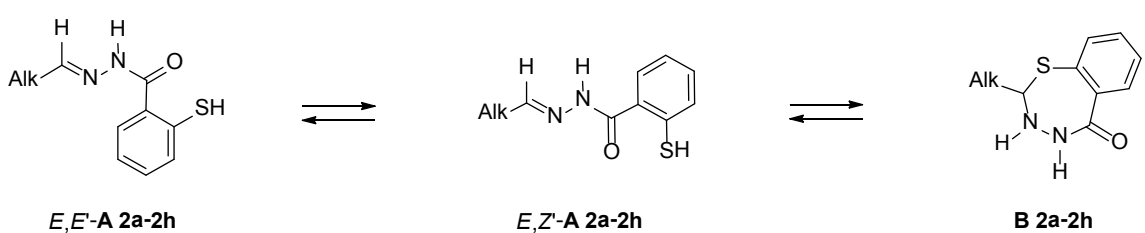

Figure 1. Tautomerism of 2-mercaptobenzoylhydrazones of aliphatic aldehydes $2 \mathbf{a}-\mathbf{2 h}$. $\mathrm{Alk}=\mathrm{H}(2 \mathrm{a}), \mathrm{Me}$ (2b), Et (2c), Bu (2d), $i$ - $\mathrm{Pr}(2 \mathrm{e}), i-\mathrm{Bu}(2 \mathrm{f}), s$-Bu (2g), $t$-Bu (2h).

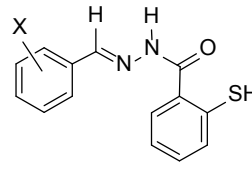

$E, E^{\prime}-\mathbf{A}$ 3a-3h

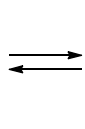<smiles>[Y]c1ccccc1C=NC(=O)c1ccccc1S</smiles>

E,Z'-A 3a-3h

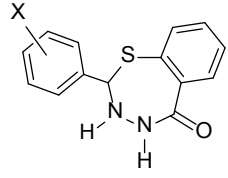

B 3a-3h

Figure 2. Tautomerism of 2-mercaptobenzoylhydrazones of aromatic aldehydes $3 \mathbf{a}-3 \mathbf{h}$. $\mathrm{X}$ $=4-\mathrm{NO}_{2}(3 \mathbf{a}), 3-\mathrm{NO}_{2}(3 \mathbf{b}), 4-\mathrm{Br}(3 \mathbf{c}), 4-\mathrm{Cl}(3 \mathbf{d}), \mathrm{H}(3 \mathbf{e}), 4-\mathrm{Me}(3 \mathbf{f}), 4-\mathrm{MeO}(3 \mathbf{g}), 4-\mathrm{Me}_{2} \mathrm{~N}$ (3h). 
NMR spectrum. It is indicated by two signals of NH protons at 5.69 and 9.44 ppm and by a doublet at $4.29 \mathrm{ppm}(\mathrm{H}-2)$, and the ${ }^{13} \mathrm{C}-\mathrm{NMR}$ spectrum of this form is characterized by the signal of $\mathrm{sp}^{3}$-hybridized atom C-2 at $58.49 \mathrm{ppm}$. Gradually in the ${ }^{1} \mathrm{H}-\mathrm{NMR}$ spectrum of compound $2 \mathrm{a}$ in $\mathrm{DMSO} d_{6}$ signals appear corresponding to the stereoisomer of the linear acylhydrazone form A: one signal of azomethine protons at $7.43 \mathrm{ppm}$ and also broadened signal of $\mathrm{NH}$ protons in the region $11.89 \mathrm{ppm}$. After some time the spectrum of compound $2 \mathrm{a}$ stopped to change indicating that the ring-chain equilibrium was attained where alongside the cyclic thiadiazepine form $\mathbf{B}$ existed one stereoisomeric modification of the linear form A. A similar situation exists for the solutions in $\mathrm{DMSO}_{6}$ of other condensation products of aliphatic aldehydes with 2-mercaptobenzoic acid hydrazide $\mathbf{2 b}-\mathbf{2} \mathbf{h}$ (Table $\mathbf{1}$ ). Transition from compounds $\mathbf{2} \mathbf{b}-\mathbf{2 d}$ having an alkyl substituent with normal structure to compounds $2 \mathrm{f}-2 \mathrm{~h}$ containing bulky isobutyl, sec-butyl, and tert-butyl groups leads to the appearance in the equilibrium of the second linear isomer and to the considerable decrease in the content of cyclic tautomer $\mathbf{B}$ in the solution.

The observed doubling of the signals of the linear form $\mathbf{A}$ in the ${ }^{1} \mathrm{H}-\mathrm{NMR}$ spectra of compounds $\mathbf{2 f}-\mathbf{2} \mathbf{h}$ must be linked with the presence of conformational $E, Z$-isomers, differing in the disposition of substituents relative to the amide $\mathrm{C}-\mathrm{N}$ bond. The existence of an $E, Z$-configuration of isomer relative to the $\mathrm{C}=\mathrm{N}$ bond was not considered by us since aldoacylhydrazones exist primarily or completely in the $E$-configuration relative to this bond [10] [11] [12] [13]. Assignment of the signals of the $E, E$ - and $E, Z$-isomers of the linear form $\mathrm{A}$ was based on the known difference in position of the signals of the azomethine protons of the conformational $E, Z$-isomers in the ${ }^{1} \mathrm{H}$-NMR spectra [14]. The signals of the $Z$-isomer of this group are disposed at lower field than the analogous signals of the $E$-isomer. An opposite value of both signals in the ${ }^{1} \mathrm{H}$-NMR spectra is observed for the protons of the NHCO groups of these conformers. Taking into consideration the above-indicated it may be confirmed that the main isomer has the $E, Z$-structure, and the minor isomer the $E, E$-spatial disposition.

Table 1. Tautomeric composition of the aliphatic aldehydes 2-mercaptobenzoyl-hydrazones $\mathbf{2 a - 2 h}$ in $\mathrm{DMSO}_{6}$.

\begin{tabular}{ccccc}
\hline \multirow{2}{*}{ Compound } & \multicolumn{2}{c}{ Tautomeric composition in $\mathrm{DMSO}_{6}, \%,(48 \mathrm{~h}$ after dissolution $)$} & \multirow{2}{*}{$\lg K_{\mathrm{T}}^{*}$} \\
\cline { 2 - 4 } & $E, E-\mathrm{A}$ & $E, Z-\mathrm{A}$ & $\mathrm{B}$ & \\
\hline $2 \mathrm{a}$ & - & 0.5 & 99.5 & 2.299 \\
$2 \mathrm{~b}$ & - & 2 & 98 & 1.690 \\
$2 \mathrm{c}$ & - & 4 & 96 & 1.380 \\
$2 \mathrm{~d}$ & - & 7 & 93 & 1.123 \\
$2 \mathrm{e}$ & - & 10 & 90 & 0.954 \\
$2 \mathrm{2f}$ & 1 & 10 & 89 & 0.908 \\
$2 \mathrm{~g}$ & 6 & 38 & 56 & 0.105 \\
$2 \mathrm{~h}$ & 12 & 61 & 27 & -0.432 \\
\hline
\end{tabular}

${ }^{*}$ Tautomeric equilibrium constant $K_{\mathrm{T}}=[\mathbf{B}] /[E, E-\mathbf{A}]+[E, Z-\mathbf{A}]$. 
The position of the equilibrium $\mathbf{A} \rightleftarrows \mathbf{B}$ depends on the length and branching of the alkyl substituent: the introduction of bulky groups into the aliphatic aldehyde component leads to a displacement of the ring-chain equilibrium to the side of the 2-mercaptobenzoylhydrazone form A (Table 1). A linear correlation is then observed between the logarithms of the tautomeric equilibrium constants $K_{\mathrm{T}}$ and the Taft $E_{\mathrm{S}}$ constant [15], [16], [17]. The use of the Palm steric constants $E_{\mathrm{S}}^{\circ}[18]$ improves the correlation (Table 2 and Figure 1 ).

By an example of compound $2 \mathrm{~h}$ we explored the effect of solvent on the tautomeric equilibrium (Table 3 ). In crystalline state compound exist as benzo1,3,4-thiadiazepine B. This proofs to be true because in its solid-phase ${ }^{13} \mathrm{C}-\mathrm{NMR}$ spectrum $\mathrm{sp}^{3}$-hybridized atom C-2 at $84.56 \mathrm{ppm}$ is present (Experimental part). In low-polar $\mathrm{CDCl}_{3}$ about $70 \%$ of cyclic benzo-1,3,4-thiadiazepine form was detected. In going to basic dipolar solvents such as $\mathrm{DMSO}_{6}$ and $\mathrm{DMF} d_{7}$ the domination of the linear form $\mathbf{A}$ was favored.

Thus the condensation products of aliphatic aldehydes with 2-mercaptobenzoic acid hydrazide $2 \mathrm{a}-2 \mathrm{~h}$ in the crystalline state possess the structure benzo1,3,4-thiadiazepine, and in solution of polar solvents they partially transform into the open-chain form $\mathbf{A}$; consequently, it is only tentatively possible to use the name "mercaptobenzoylhydrazone" for such compounds.

In the series of aromatic aldehydes 2-mercaptobenzoylhydrazones $3 \mathrm{a}-3 \mathrm{~h}$ the ring-chain tautomeric equilibrium should shift to the open-chain form $\mathbf{A}$ for the latter is stabilized by involving the aromatic ring in the system of $\pi$-p- $\pi$-conjugation of the acylhydrazone fragment [10] [12]. This assumption was completely confirmed by the study of ${ }^{1} \mathrm{H}$ - and ${ }^{13} \mathrm{C}-\mathrm{NMR}$ spectra of compounds $3 \mathrm{a}-3 \mathbf{h}$ (Figure 2).

Table 2. Correlation of the logarithms of the tautomeric equilibrium constants $K_{\mathrm{T}}$ of compounds $2 \mathrm{a}-2 \mathrm{~h}$ with substituent constants of Taft $E_{S}$ and Palm $E_{S}^{\circ}$ according to the equation: $\lg K_{T}=a+\rho \cdot X ;(n=8)$.

\begin{tabular}{ccccc}
\hline$X$ & $a$ & $\rho$ & $r$ & $s_{\mathrm{D}}$ \\
\hline$E_{S}$ & $1.398 \pm 0.116$ & $0.960 \pm 0.129$ & 0.949 & 0.292 \\
$E_{S}^{\circ}$ & $1.852 \pm 0.084$ & $1.068 \pm 0.077$ & 0.985 & 0.161 \\
\hline
\end{tabular}

Table 3. Tautomeric composition of trimethylacetic aldehyde 2-mercaptobenzoyl-hydrazone $2 \mathrm{~h}$ in different solvents.

\begin{tabular}{cccc}
\hline \multirow{2}{*}{ Solvent } & \multicolumn{3}{c}{ Tautomeric composition, \%, (48 h after dissolution) } \\
\cline { 2 - 4 } & Form $E, E-\mathbf{A}$ & Form $E, Z-\mathbf{A}$ & Form B \\
\hline Solid phase & - & - & 100 \\
$\mathrm{CDCl}_{3}$ & - & 30 & 70 \\
Pyridine $_{5}$ & 6 & 37 & 57 \\
$\operatorname{DMF}_{7}$ & 10 & 46 & 44 \\
$\operatorname{DMSO}_{6}$ & 12 & 61 & 27 \\
\hline
\end{tabular}


In the ${ }^{1} \mathrm{H}-\mathrm{NMR}$ spectra of solutions in $\mathrm{DMSO}_{6}$ of all the synthesized compounds $3 \mathrm{a}-3 \mathrm{~h}$ there were signals corresponding both to the linear $\mathbf{A}$ and to the cyclic benzo-1,3,4-thiadiazepine $\mathbf{B}$ tautomeric forms. The signals of the linear 2-mercaptobenzoylhydrazone tautomer A were doubled in the spectra (Table 4). The observed doubling of the signals of the linear form $\mathbf{A}$ in the ${ }^{1} \mathrm{H}-\mathrm{NMR}$ spectra of compounds $3 \mathrm{a}-3 \mathrm{~h}$ must be linked with the presence of conformational $E, Z$-isomers, differing in the disposition of substituents relative to the amide $\mathrm{C}-\mathrm{N}$ bond. An $E, Z$-structure must therefore be attributed to the main isomer whereas $E, E$-structural disposition to the minor isomer.

The existence of an $E, Z$-configuration of isomer relative to the $\mathrm{C}=\mathrm{N}$ bond was not considered by us since aldoacylhydrazones exist primarily or completely in the $E$-configuration relative to this bond [10], [12]. The assignment of signals belonging to $E, E$ - and $E, Z$-isomers of linear form $\mathrm{A}$ was based on the known difference in the chemical shifts of the carbon atoms in the $\mathrm{C}=\mathrm{N}$ and $\mathrm{C}=\mathrm{O}$ bonds in the ${ }^{13} \mathrm{C}$-NMR spectra of conformational isomers of monocarbonyl compounds acylhydrazones; the $E$-isomer signals of these groups were located in the region of 145 and $170 \mathrm{ppm}$, whereas those of $Z$-isomer, at 150 and $160 \mathrm{ppm}$ respectively [3] [12] [13]. In view of the above the major isomer of compounds $3 a-3 h$ had $E, Z$-configuration, and the structural arrangement of the minor isomer was $E, E$-configuration. The existence of the cyclic form $\mathbf{B}$ in solution may be judged in the ${ }^{1} \mathrm{H}-\mathrm{NMR}$ spectra by the doublet signals of the $\mathrm{H}-2$ and NHCO protons at 5.76 and $9.62 \mathrm{ppm}$ respectively and also by the doublet-doublet signals of the $\mathrm{NH}$ group proton at $6.25 \mathrm{ppm}$, which is caused by a spin-spin interaction with the protons in positions 2 and 4 of the benzo-1,3,4-thiadiazepine cycle (Experimental part).

The introduction of an electron-withdrawing substituent into the aromatic ring of the aldehyde component leads to a displacement of the ring-chain equilibrium $\mathbf{A} \rightleftarrows \mathbf{B}$ to the side of the cyclic benzo-1,3,4-thiadiazepine form $\mathbf{B}$, and a linear correlation is then observed between the logarithms of the tautomeric equilibrium constants $K_{\mathrm{T}}$ and the Hammett $\sigma$-constant [16] [19]. The use of the $\sigma^{+}$-constant of Brown [20] improves the correlation (Table 5 and Figure 3). The

Table 4. Tautomeric composition of the aromatic aldehydes 2-mercaptobenzoyl-hydrazones $3 \mathrm{a}-3 \mathrm{~h}$ in $\mathrm{DMSO}_{6}$.

\begin{tabular}{|c|c|c|c|c|}
\hline \multirow{2}{*}{ Compound } & \multicolumn{3}{|c|}{ Tautomeric composition in $\mathrm{DMSO} d_{6}, \%,(48 \mathrm{~h}$ after dissolution) } & \multirow{2}{*}{$\lg K_{\mathrm{T}}^{*}$} \\
\hline & $E, E-\mathrm{A}$ & $E, Z-\mathrm{A}$ & B & \\
\hline $3 a$ & 6 & 51 & 43 & -0.122 \\
\hline $3 b$ & 6 & 53 & 41 & -0.158 \\
\hline $3 c$ & 9 & 54 & 37 & -0.231 \\
\hline $3 d$ & 9 & 56 & 35 & -0.269 \\
\hline $3 e$ & 10 & 61 & 29 & -0.389 \\
\hline $3 f$ & 10 & 63 & 27 & -0.432 \\
\hline $3 g$ & 11 & 72 & 17 & -0.689 \\
\hline $3 \mathrm{~h}$ & 13 & 80 & 7 & -1.123 \\
\hline
\end{tabular}

${ }^{\star}$ Tautomeric equilibrium constant $K_{\mathrm{T}}=[\mathbf{B}] /[E, E-\mathbf{A}]+[E, Z-\mathbf{A}]$. 

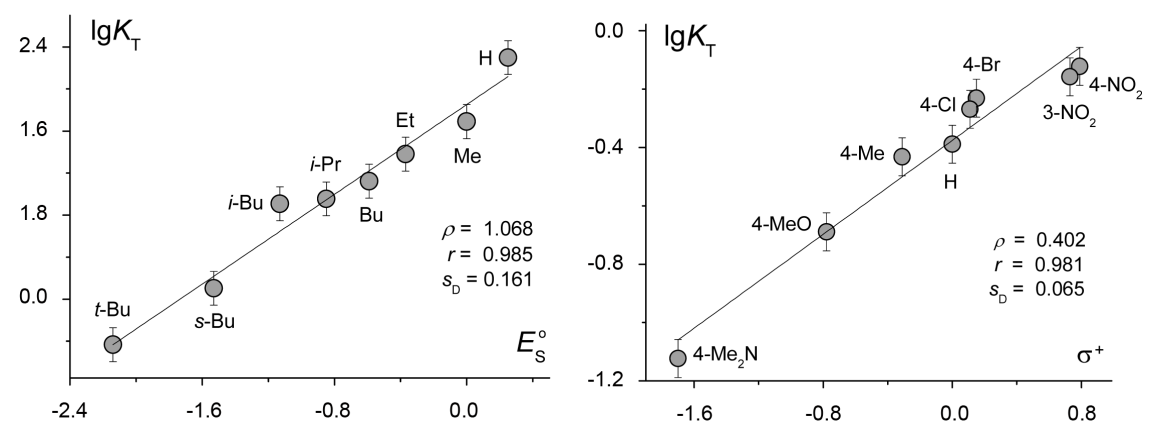

Figure 3. Plots of the tautomeric equilibrium $K_{\mathrm{T}}$ logarithms correlation of compounds 2a-2h and $3 \mathrm{a}-3 \mathrm{~h}$ respectively with substituent constants: of Palm $E_{S}^{\circ}$ alkyl substituent constants (left), of Brown $\sigma^{+}$substituent constants (right).

Table 5. Correlation of the logarithms of the tautomeric equilibrium constants $K_{\mathrm{T}}$ of compounds $3 \mathrm{a}-3 \mathrm{~h}$ with substituent constants of Hammett $\sigma$ and Brown $\sigma^{+}$according to the equation: $\lg K_{T}=a+\rho \cdot X ;(n=8)$.

\begin{tabular}{ccccc}
\hline$X$ & $a$ & $\rho$ & $r$ & $s_{\mathrm{D}}$ \\
\hline$\sigma$ & $-0.477 \pm 0.045$ & $0.595 \pm 0.090$ & 0.938 & 0.125 \\
$\sigma^{+}$ & $-0.376 \pm 0.025$ & $0.402 \pm 0.033$ & 0.981 & 0.065 \\
\hline
\end{tabular}

same regularity is explained by the fact that the electron-withdrawing substituents strengthen the electrophilicity of the carbon atom of the $\mathrm{C}=\mathrm{N}$ bond, addition of the SH function to which leads to the formation of benzo-1,3,4-thiadiazepine tautomer $\mathbf{B}$. The conformational equilibria within the linear tautomer are sensitive to a lesser extent to the nature of the substituent in the aromatic ring. Probably in both linear forms $E, E-\mathrm{A}$ and $E, Z$-A identical systems of conjugation occur, reacting in the same way to the change of electronic parameters of the substituent (Table 4).

In a much greater extent the position of the tautomeric equilibrium is dependent on the nature of solvent used. This was demonstrated by the example of 4chlorobenzoic aldehyde 2-mercaptobenzoylhydrazone $3 \mathrm{~d}$ (Table 6). The openchain structure $E, Z$-A of compound $3 \mathrm{~d}$ in crystalline state was confirmed by its solid-phase ${ }^{13} \mathrm{C}-\mathrm{NMR}$ spectrum: $150.74(\mathrm{C}=\mathrm{N}), 166.55(\mathrm{C}=\mathrm{O})$ ppm (Experimental part). The same form was detected under the study of the spectrum of compound 3d taking of in $\mathrm{CDCl}_{3}$. In going to basic dipolar solvents such as $\mathrm{DMSO}_{6}$ and $\mathrm{DMF} d_{7}$ the domination of the benzo-1,3,4-thiadiazepine form $\mathbf{B}$ was favored. Perhaps, its stabilization is due to the possibility of hydrogen bonds formation between the NH groups of the benzo-1,3,4-thiadiazepine ring and the polar solvent molecules.

\section{Conclusions}

Therefore, in contrast to the products of the condensation of aldehydes with the hydrazides of 2-hydroxy- and 2-aminobenzoic acids reported in the literature [8] [9], 2-mercaptobenzoylhydrazones of aliphatic and aromatic aldehydes display a tendency to cyclize to give the seven-membered 1,3,4-benzothiadiazepine 
Table 6. Tautomeric composition of 4-chlorobenzoic aldehyde 2-mercaptobenzoyl-hydrazone $\mathbf{3 d}$ in different solvents.

\begin{tabular}{cccc}
\hline & \multicolumn{3}{c}{ Tautomeric composition, \%, (48 h after dissolution) } \\
\cline { 2 - 4 } Solvent & Form $E, E-\mathbf{A}$ & Form $E, Z-\mathrm{A}$ & Form B \\
\hline Solid phase & - & 100 & - \\
$\mathrm{CDCl}_{3}$ & - & 100 & - \\
Pyridined $_{5}$ & 16 & 71 & 13 \\
DMF $_{7}$ & 8 & 58 & 34 \\
DMSO $_{6}$ & 9 & 56 & 35 \\
\hline
\end{tabular}

ring. This naturally reflects the greater nucleophilicity of the sulfur atom of the $\mathrm{SH}$ function, which participates in intramolecular cyclization, in comparison with the nucleophilicity of the oxygen and nitrogen atoms in the $\mathrm{OH}$ and $\mathrm{NH}$ functions in the hydrazones obtained using 2-hydroxy- and 2-aminobenzoic acid hydrazides. In this regard, 2-mercaptobenzoylhydrazones are similar to the products of the condensation of carbonyl compounds with thiobenzoic and thioglycolic acid hydrazides, for which intramolecular attack by the sulfur atom at the $\mathrm{C}=\mathrm{N}$ bond of the hydrazone fragment leads to formation of 1,3,4-thiadiazoline [21] and 1,3,4-thiadiazine rings [7] [12], respectively. The determination of the conformational state of the seven-membered 1,3,4-benzothiadiazepine ring requires further study.

\section{Experimental Part}

\subsection{General Methods}

${ }^{1} \mathrm{H}$-and ${ }^{13} \mathrm{C}$-NMR spectra were registered on a spectrometer Bruker AV-400 at operating frequencies 400 and $100 \mathrm{MHz}$ respectively (internal reference hexamethyldisiloxane). The solid-phase ${ }^{13} \mathrm{C}$-NMR spectra were obtained on a Bruker AM-500 spectrometer (125 MHz) using a standard procedure utilizing cross polarization and magic angle spinning (CPMAS) technique (frequency $4.5 \mathrm{kHz}$; internal reference hexamethylbenzene). The tautomeric composition of obtained compounds was estimated by the integration of the appropriate signals in the ${ }^{1} \mathrm{H}$ NMR spectra, and error of measurement was $\pm 1 \%$. Elemental analysis of previously unknown compounds was carried out on a CHN Analyzer Hewlett Packard 185B. The purity of prepared compounds was checked by TLC on Silufol UV- 254 plates, eluent benzene-acetone, 4:1. 2-Mercaptobenzoic acid hydrazide 1 was obtained by method [22].

\subsection{Synthesis of 2-Mercaptobenzoylhydrazones 2 and 3 (General Procedure)}

To a solution of 2-mercaptobenzohydrazide 1 (1.68 g, $10 \mathrm{mmol})$ in methanol (25 $\mathrm{ml}$ ) an appropriate aldehyde $(11 \mathrm{mmol}$ ) was added (for compound $2 \mathrm{a} 1.0 \mathrm{ml}$ of $40 \%$ formaline was used), and the mixture was kept at room temperature for a 
period of $10-15 \mathrm{~min}$. The solvent was removed at a reduced pressure, and the residue was washed with ether $(3 \times 25 \mathrm{ml})$, filtered off, dried and recrystallizated.

Physico-chemical and spectral characteristics of compounds $\mathbf{2 b - 2 f}$ and $\mathbf{3 a}-\mathbf{3 c}$, 3e-3h were described previously [23] [24].

\subsection{Formic Aldehyde 2-Mercaptobenzoylhydrazone (2a)}

Yield 54\%, m.p. $201^{\circ}-203^{\circ}$ (acetonitrile) (m.p. [22] 203 $-206^{\circ}$ ). ${ }^{1} \mathrm{H}-\mathrm{NMR}$ spectrum $\left(\mathrm{DMSOd}_{6}\right): \delta=$ form $E, Z-\mathrm{A}(0.5 \%): 11.89$ (br.s, NHCO), 7.43 (br.s, $\mathrm{HC}=\mathrm{N}$ ); form B (99.5\%): $4.29(\mathrm{~d}, \mathrm{~J}=7.8 \mathrm{~Hz}, \mathrm{H}-2), 5.69\left(\mathrm{dt}, \mathrm{J}_{1}=7.8 \mathrm{~Hz}, \mathrm{~J}_{2}=5.0\right.$ $\mathrm{Hz}, \mathrm{NH}$ ), $7.47-7.60$ (Ar in $E, Z-\mathbf{A}$ and $\mathbf{B}), 9.44(\mathrm{~d}, \mathrm{~J}=5.0 \mathrm{~Hz}, \mathrm{NHCO}) \mathrm{ppm}$. ${ }^{13} \mathrm{C}-\mathrm{NMR}$ spectrum (DMSO $d_{6}$ ): $\delta=$ form B: 58.49 (C-2), $128.42-140.96(\mathrm{Ar})$, 173.60 (C-5) ppm. Found, \%: C 53.26; H, 4.53; N, 15.49. $\mathrm{C}_{8} \mathrm{H}_{8} \mathrm{~N}_{2} \mathrm{OS}$. Calculated, \%: C 53.31, H 4.47, N 15.54 .

\subsection{2-Methylbutyric Aldehyde 2-Mercaptobenzoylhydrazone (2g)}

Yield $63 \%$, m.p. $88^{\circ} \mathrm{C}-91^{\circ} \mathrm{C}$ (benzene - hexane, 1:4). ${ }^{1} \mathrm{H}-\mathrm{NMR}$ spectrum $\left(\mathrm{DMSO}_{6}\right): \delta=$ form $E, E-\mathrm{A}(6 \%): 0.86\left(\mathrm{t}, \mathrm{J}=7.4 \mathrm{~Hz}, \mathrm{CH}_{3} \mathrm{CH}_{2}\right), 0.97(\mathrm{~d}, \mathrm{~J}=6.5$ $\left.\mathrm{Hz}, \mathrm{CH}_{3} \mathrm{CH}\right), 1.06\left(\mathrm{~m}, \mathrm{CH}_{3} \mathrm{CH}_{2}\right), 1.40\left(\mathrm{~m}, \mathrm{CH}_{3} \mathrm{CH}\right), 7.44(\mathrm{~d}, \mathrm{~J}=4.2 \mathrm{~Hz}, \mathrm{HC}=\mathrm{N})$, 11.98 (br.s, $\mathrm{NHCO}$ ), form $E, \mathrm{Z}^{\prime}-\mathrm{A}(38 \%)$ : 0.86 (t, J = 7.4 Hz, $\mathrm{CH}_{3} \mathrm{CH}_{2}$ ), 0.97 (d, J $\left.=6.5 \mathrm{~Hz}, \mathrm{CH}_{3} \mathrm{CH}\right), 1.21\left(\mathrm{~m}, \mathrm{CH}_{3} \mathrm{CH}_{2}\right), 1.51\left(\mathrm{~m}, \mathrm{CH}_{3} \mathrm{CH}\right), 7.60(\mathrm{~d}, \mathrm{~J}=4.2 \mathrm{~Hz}$, $\mathrm{HC}=\mathrm{N}$ ), 11.57 (br.s, NHCO), form B (56\%): $0.84\left(\mathrm{t}, \mathrm{J}=7.2 \mathrm{~Hz}, \mathrm{CH}_{3} \mathrm{CH}_{2}\right), 0.90$ (d, J = 6.4 Hz, CH$\left.{ }_{3} \mathrm{CH}\right), 1.65\left(\mathrm{~m}, \mathrm{CH}_{3} \mathrm{CH}\right), 1.75\left(\mathrm{~m}, \mathrm{CH}_{3} \mathrm{CH}_{2}\right), 4.43\left(\mathrm{dd}, \mathrm{J}_{1}=7.5\right.$ $\left.\mathrm{Hz}, \mathrm{J}_{2}=5.5 \mathrm{~Hz}, \mathrm{H}-2\right), 5.74\left(\mathrm{dd}, \mathrm{J}_{1}=5.5 \mathrm{~Hz}, \mathrm{~J}_{2}=5.0 \mathrm{~Hz}, \mathrm{NH}\right), 7.42-7.62(\mathrm{Ar}$ in $\mathbf{A}$ and B), $9.44(\mathrm{~d}, \mathrm{~J}=5.0 \mathrm{~Hz}, \mathrm{NHCO}) \mathrm{ppm} .{ }^{13} \mathrm{C}-\mathrm{NMR}$ spectrum $\left(\mathrm{DMSO}_{6}\right): \delta=$ form $E$, E-A: $11.43\left(\mathrm{CH}_{3}\right), 17.14\left(\mathrm{CH}_{3}\right), 26.97\left(\mathrm{CH}_{2}\right), 166.89(\mathrm{C}=\mathrm{O})$, form $E, Z$-A: 11.54 $\left(\mathrm{CH}_{3}\right), 16.19\left(\mathrm{CH}_{3}\right), 25.59\left(\mathrm{CH}_{2}\right), 37.85(\mathrm{CH}), 156.91(\mathrm{C}=\mathrm{N}), 163.07(\mathrm{C}=\mathrm{O})$, form $\mathrm{B}: 10.95\left(\mathrm{CH}_{3}\right), 15.32\left(\mathrm{CH}_{3}\right), 26.17\left(\mathrm{CH}_{2}\right), 38.59(\mathrm{CH}), 78.72(\mathrm{C}-2), 128.17$ 140.39 (Ar in A and B), 173.16 (C-5) ppm. Found, \%: C 60.94; H 6.88; N 11.90. $\mathrm{C}_{12} \mathrm{H}_{16} \mathrm{~N}_{2} \mathrm{OS}$. Calculated, \%: C 60.99; H 6.82; N 11.85 .

\subsection{Trimethylacetyc Aldehyde 2-Mercaptobenzoylhydrazone (2h)}

Yield 57\%, m.p. $132^{\circ} \mathrm{C}-134^{\circ} \mathrm{C}$ (benzene - hexane, $\left.1: 4\right) .{ }^{13} \mathrm{C}-\mathrm{NMR}$ spectrum (solid phase): $\delta=$ form B (100\%): $27.12\left(\left(\mathrm{CH}_{3}\right)_{3} \mathrm{C}\right), 35.07\left(\left(\mathrm{CH}_{3}\right)_{3} \mathrm{C}\right), 84.56(\mathrm{C}-2)$, 126.84 - 142.21 (Ar), $174.79(\mathrm{C}-5) \mathrm{ppm} .{ }^{1} \mathrm{H}-\mathrm{NMR}$ spectrum (DMSO $d_{6}$ ): $\delta=$ form E,E-A (12\%): $0.95\left(\mathrm{~s},\left(\mathrm{CH}_{3}\right)_{3} \mathrm{C}\right), 7.60(\mathrm{~s}, \mathrm{HC}=\mathrm{N}), 11.81$ (br.s, NHCO), E,Z-A (61\%): $1.11\left(\mathrm{~s},\left(\mathrm{CH}_{3}\right)_{3} \mathrm{C}\right), 7.65$ (s, HC=N), 11.54 (br.s, NHCO), form B (27\%): $0.97\left(\mathrm{~s},\left(\mathrm{CH}_{3}\right)_{3} \mathrm{C}\right), 4.40(\mathrm{~d}, \mathrm{~J}=9.5 \mathrm{~Hz}, \mathrm{H}-2), 5.63\left(\mathrm{dd}, \mathrm{J}_{1}=9.5 \mathrm{~Hz}, \mathrm{~J}_{2}=5.0 \mathrm{~Hz}\right.$, $\mathrm{NH}), 7.34-7.66$ ( $\mathrm{Ar}$ in $\mathbf{A}$ and B), $9.41(\mathrm{~d}, \mathrm{~J}=5.0 \mathrm{~Hz}, \mathrm{NHCO}) \mathrm{ppm} .{ }^{13} \mathrm{C}-\mathrm{NMR}$ spectrum $\left(\mathrm{DMSO}_{6}\right): \delta=$ form $E, E-\mathrm{A}: 27.06\left(\left(\mathrm{CH}_{3}\right)_{3} \mathrm{C}\right), 36.80\left(\left(\mathrm{CH}_{3}\right)_{3} \mathrm{C}\right), 147.86$ $(\mathrm{C}=\mathrm{N}), 163.04(\mathrm{C}=\mathrm{O})$, form $E, Z-\mathrm{A}: 27.06\left(\left(\mathrm{CH}_{3}\right)_{3} \mathrm{C}\right), 36.80\left(\left(\mathrm{CH}_{3}\right)_{3} \mathrm{C}\right), 150.43$ $(\mathrm{C}=\mathrm{N}), 159.88(\mathrm{C}=\mathrm{O})$, form B: $27.24\left(\left(\mathrm{CH}_{3}\right)_{3} \mathrm{C}\right), 34.72\left(\left(\mathrm{CH}_{3}\right)_{3} \mathrm{C}\right), 84.22(\mathrm{C}-2)$, 126.24 - 140.33 (Ar in A and B), 173.00 (C-5) ppm. Found, \%: C 61.03; H 6.76; N 11.91. $\mathrm{C}_{12} \mathrm{H}_{16} \mathrm{~N}_{2} \mathrm{OS}$. Calculated, \%: C 60.99; H 6.82; N 11.85. 


\subsection{4-Chlorobenzoic Aldehyde 2-Mercaptobenzoylhydrazone (3d)}

Yield $76 \%$, m.p. $181^{\circ} \mathrm{C}-183^{\circ} \mathrm{C}$ (ethanol). ${ }^{13} \mathrm{C}-\mathrm{NMR}$ spectrum (solid phase): $\delta=$ form $E, Z$-A (100\%): 125.00 - $132.21(\mathrm{Ar}), 150.74(\mathrm{C}=\mathrm{N}), 166.55(\mathrm{C}=\mathrm{O}) \mathrm{ppm} .{ }^{1} \mathrm{H}-$ NMR spectrum $\left(\mathrm{DMSO}_{6}\right)$ : form $E, E-\mathrm{A}(9 \%): 8.12$ (s, $\left.\mathrm{HC}=\mathrm{N}\right), 12.13$ (br.s, $\mathrm{NHCO}$ ), form $E, Z$-A (56\%): 8.40 (s, HC=N), 11.96 (br.s, NHCO), form B (35\%): $5.76(\mathrm{~d}, \mathrm{~J}=6.9 \mathrm{~Hz}, \mathrm{H}-2), 6.25\left(\mathrm{dd}, \mathrm{J}_{1}=6.9 \mathrm{~Hz}, \mathrm{~J}_{2}=3.8 \mathrm{~Hz}, \mathrm{NH}\right), 7.38-7.76(\mathrm{Ar}$ in $\mathrm{A}$ and $\mathrm{B}), 9.62(\mathrm{~d}, \mathrm{~J}=3.8 \mathrm{~Hz}, \mathrm{NHCO}) \mathrm{ppm} .{ }^{13} \mathrm{C}-\mathrm{NMR}$ spectrum $\left(\mathrm{DMF} d_{7}\right): \delta=$ form $E, E-\mathrm{A}: 141.21(\mathrm{C}=\mathrm{N}), 173.28(\mathrm{C}=\mathrm{O})$, form $E, Z-\mathrm{A}: 147.00(\mathrm{C}=\mathrm{N}), 164.82$ $(\mathrm{C}=\mathrm{O})$, form B: 73.95 (C-5), 173.90 (C-5), 124.79 - 139.10 (Ar in A and B) ppm. Found, \%: C 57.78; $\mathrm{H}$ 3.77; $\mathrm{N}$ 9.79. $\mathrm{C}_{14} \mathrm{H}_{11} \mathrm{ClN}_{2} \mathrm{OS}$. Calculated, \%: C 57.83; $\mathrm{H}$ $3.81 ; \mathrm{N} 9.63$.

\section{References}

[1] Majumdar, P., Pati, A., Patra, M., Behera, R.K. and Behera, A.K. (2014) Acid Hydrazides, Potent Reagents for Synthesis of Oxygen-, Nitrogen-, and/or Sulfur-Containing Heterocyclic Rings. Chemical Reviews, 114, 2942-2977.

https://doi.org/10.1021/cr300122t

[2] El-Barbary, A.A., El-Ezz, A.Z.A., Sharaf, A.M. and Nielsen, C. (2006) The Synthesis of Some New Quinazolone Derivatives of Potential Biological Activity. Phosphorus, Sulfur, and Silicon and the Related Elements, 181, 1895-1912. https://doi.org/10.1080/10426500500543834

[3] Ershov, A.Yu., Chernitsa, B.V., Doroshenko, V.A., Yakimovich, S.I., Alekseev, V.V., Lagoda, I.V., Pakalnis, V.V., Zerova, I.V. and Shamanin, V.V. (2011) N-2-Aminobenzoyl-N-Methylhydrazones of Aldehydes and Aldoses and Their Cyclization into Benzo-1,3,4-Triazepine Derivatives. Chemistry of Heterocyclic Compounds, 46, 1838-1848. https://doi.org/10.1007/s10593-011-0697-0

[4] Valters, R.E. and Flitsch, W. (1985) Ring-Chain Tautomerism. Plenum Press, New York, 290 p. https://doi.org/10.1007/978-1-4684-4883-2

[5] Elguero, J., Marzin, C., Katrizky, A.R. and Linda, P. (1976) The Tautomerism of Heterocycles. Academic Press, New York, London, 655 p.

[6] Lázár, L. and Fülöp, F. (2003) Recent Developments in the Ring-Chain Tautomerism of 1,3-Heterocycles. European Journal of Organic Chemistry, 16, 3025-3042. https://doi.org/10.1002/ejoc.200300142

[7] Ershov, A.Yu., Lagoda, I.V., Yakimovich, S.I., Pakalnis, V.V. and Shamanin, V.V. (2007) Ring-Chain Tautomerism of the Condensation Product of Acetone with 2Sulfanylbenzohydrazide. Russian Journal of Organic Chemistry, 43, 1745-1746. https://doi.org/10.1134/S1070428007110310

[8] Flegontov, S.A., Titova, Z.S., Stolyarov, A.P., Buzykin, B.I. and Kitaev, Yu.P. (1979) Hydrazones 62. The Structures of Aroylhydrazones with Intramolecular Hydrogen Bonding. Bulletin of the Academy of Sciences of the USSR, Division of Chemical Science, 28, 948-953. https://doi.org/10.1007/BF00963303

[9] Neuvonen, K., Fülöp, F., Neuvonen, H., Simeonov, M. and Pihlaja, K. (1997) Correlation Analysis of the ${ }^{13} \mathrm{C}$ Chemical Shifts of Substituted Benzaldehyde 2-Aminobenzoylhydrazones. Study of the Propagation of Substituent Effects along a Heteroatomic Chain. Journal of Physical Organic Chemistry, 10, 55-66. https://doi.org/10.1002/(SICI)1099-1395(199701)10:1<55::AID-POC854>3.0.CO;2$\underline{\mathrm{D}}$ 
[10] Kitaev, Yu.P. and Buzykin, B.I. (1974) Hydrazones. Nauka, Moscow, 381 p. (In Russian)

[11] Parpiev, N.A., Yusupov, V.G., Yakimovich, S.I. and Sharipov, Kh.T. (1988) Acylhydrazones and Their Complexes with Transition Metals. Fan, Tashkent, 163 p. (In Russian)

[12] Ershov, A.Yu., Lagoda, I.V., Yakimovich, S.I., Pakalnis, V.V., Zerova, I.V., Dobrodumov, A.V. and Shamanin, V.V. (2009) Tautomerism and Conformational Isomerism of Mercaptoacetylhydrazones of Aliphatic and Aromatic Aldehydes. Russian Journal of Organic Chemistry, 45, 660-666. https://doi.org/10.1134/S1070428009050030

[13] Ershov, A.Yu., Lagoda, I.V., Yakimovich, S.I., Zerova, I.V., Pakalnis, V.V. and Shamanin, V.V. (2009) Structure of the Condensation Products of 3-Sulfanylpropionic acid Hydrazide with Aldehydes, Ketones, and Aldoses. Russian Journal of Organic Chemistry, 45, 1488-1495. https://doi.org/10.1134/S107042800910011X

[14] Karabatsos, G.J., Draham, J.D. and Vane, F.M. (1962). syn-anti Isomer Determination of 2,4-Dinitrophenylhydrazones and Semicarbazones by N.M.R. Journal of American Chemical Society, 84, 753-755. https://doi.org/10.1021/ja00864a015

[15] Taft, R.W. (1952) Linear Free Energy Relationships from Rates of Esterification and Hydrolysis of Aliphatic and Ortho-Substituted Benzoate Esters. Journal of American Chemical Society, 74, 2729-2732. https://doi.org/10.1021/ja01131a010

[16] Zhdanov, Yu.A. and Minkin, V.I. (1966) Correlation Analysis in Organic Chemistry. Rostov University, Rostov-on-Don, 470 p. (In Russian)

[17] Charton, M. (1975) Steric Effects. I. Esterification and Acid-Catalyzed Hydrolysis of Esters. Journal of American Chemical Society, 97, 1552-1556. https://doi.org/10.1021/ja00839a047

[18] Palm, V.A. (1977) Fundamentals of the Quantitative Theory of Organic Reactions. Khimia, Leningrad, 360 p. (In Russian)

[19] Hammett, L.P. (1937) The Effect of Structure upon the Reactions of Organic Compounds. Benzene Derivatives. Journal of American Chemical Society, 59, 96-103. https://doi.org/10.1021/ja01280a022

[20] Brown, H.C. and Okamoto, Y. (1958) Electrophylic Substituent Constants. Journal of American Chemical Society, 80, 4979-4987. https://doi.org/10.1021/ja01551a055

[21] Zelenin, K.N., Alekseev, V.V., Kuznetsova, O.B., Terentev, P.B., Lashin, V.V., Ovcharenko, V.V. and Khorseeva, L.A. (1993) Thiosemicarbazones, thiobenzoylhydrazones and Thiocarbonohydrazones of Monoses. Russian Journal of Organic Chemistry, 29, 278-286.

[22] Katz, L., Karger, L.S., Schroeder, W. and Cohen, M.S. (1953) Hydrazine Derivatives. I. Benzalthio- and Bisbenzaldi-Thiosalicylhydrazides. Journal of Organic Chemistry, 18, 1380-1402. https://doi.org/10.1021/jo50016a019

[23] Ershov, A.Yu., Lagoda, I.V., Mokeev, M.V., Yakimovich, S.I., Zerova, I.V., Pakalnis, V.V. and Shamanin, V.V. (2008) Thiosalicyloylhydrazones of Alyphatic Aldehydes and Their Cyclization into 1,3,4-Benzothiadiazepine Derivatives. Chemistry of Heterocyclic Compounds, 44, 356-359. https://doi.org/10.1007/s10593-008-0052-2

[24] Chernitsa, B.V., Ershov, A.Yu., Doroshenko, V.A., Yakimovich, S.I., Lagoda, I.V., Zerova, I.V., Pakal'nis, V.V. and Shamanin, V.V. (2010) Ring-Chain Tautomerism of 2-Mercaptobenzoylhydrazones of Aromatic Aldehydes. Chemistry of Heterocyclic Compounds, 46, 1133-1137. https://doi.org/10.1007/s10593-010-0638-3 
Submit or recommend next manuscript to OALib Journal and we will provide best service for you:

- Publication frequency: Monthly

- 9 subject areas of science, technology and medicine

- Fair and rigorous peer-review system

- Fast publication process

- Article promotion in various social networking sites (LinkedIn, Facebook, Twitter, etc.)

- Maximum dissemination of your research work

Submit Your Paper Online: Click Here to Submit

Or Contact service@oalib.com 